\title{
Quality teaching and values education: coalescing for effective learning
}

Terence Lovat \& Neville Clement The University of Newcastle AUSTRALIA

\begin{abstract}
Awareness of the potential of quality teaching to impact upon student achievement is an outcome of recent school-effectiveness research. This research has extended the understanding of the conception of 'teacher' beyond surface factual learning to that of induction into learning of intellectual depth which engages the more sophisticated skills of ‘communicative capacity’ and ‘self-reflection'. Habermas provides a conceptual framework for this expanded notion through the awareness that knowing extends beyond factual knowledge to the challenge of 'communicative knowledge' and 'self-reflection'. Quality teaching alerts educators to the potential of the role of explicit teaching in values education and, in turn, values education has the capacity to complete and even correct the implicit goals of quality teaching. In terms of this latter, values education has potential to remind individuals and systems that it is the affective and relational aspects of teaching that ultimately give it its power and effect. Data from the Australian Government’s ‘Values Education Good Practice Schools’ project (VEGPS) are offered as evidential support for this hypothesis.
\end{abstract}




\section{Introduction}

Quality teaching is a notion that has arisen as a result of educational research, principally of the last two decades, concerned with identifying the factors that impact most directly on student achievement and wellbeing. Although quality teaching is not defined as a particular teaching method, it entails the application of contextually suitable and appropriate pedagogies to engage the full learning capacities of students.. In a quality teaching regime, therefore, teaching and learning are not perceived to be simply the transmission and reception of knowledge, but rather as providing those conditions where both students and teachers are actively, critically and reflectively engaged in knowledge-making and growing as human persons. Such a regime is therefore taken to be one that provides for the full range of developmental needs in students, intellectual, social, emotional, moral and spiritual (Lovat \& Toomey, 2007).

The research that impelled the notion of quality teaching, as defined above, contradicted earlier reports into school effectiveness and student achievement by Coleman (Coleman et al., 1966) and Jencks (Jencks \& et al., 1972) where student achievement was attributed principally the heritage factor, with schools having little impact on student outcomes. Likewise, the Plowden Report (Central Advisory Council for Education, UK, 1967) concluded that schools had minimal influence on students’ academic success (Reynolds, Hargreaves, \& Blackstone, 1980). These reports presented a pessimistic view of the power of teachers and education generally to influence student achievement, on the basis that social and economic disadvantage were the more powerful determinants. Similar pessimistic conclusions were reached in relation to moral education, with serious doubts being raised about the efficacy and appropriateness of schools teaching values, morality or character (see Cunningham, 
2005; Leming, 1993; Lickona, 1993). This resulted in a de facto values-neutral stance being taken in many schools and systems, especially in the public arena, a valuesneutrality built on the belief that educational interventions were both ethically inappropriate and educationally doomed. Such pessimism regarding the power of educational interventions, both on students' academic achievement and their moral formation, was challenged by the seemingly powerful effects of quality teaching and recognition of the implausibility and inadequacy of a values-neutral approach (Lovat \& Toomey, 2007).

Of late, there has been a renewed worldwide interest in values education in the variety of forms it takes. These include moral, character, civics or citizenship education in response to the need to discover new ways of dealing with the persistent problems of racism, drug abuse, domestic violence, sexual abuse, AIDS, and new terrorisms inspired by the most explicit of values-based beliefs. Of arguably greater importance, however, is updated research identifying the inextricable link between values and attempts to inculcate the practice and effects of quality teaching.

In order to respond to the challenges wrought by this updated research, values education must transcend any vestiges of a perception that its pertinence is merely to those schools and systems (normally private and religious) where moral formation is accepted as a standard obligation of teaching and schooling. This new research makes it clear that values education is an inextricable part of any effective teaching and schooling because it goes to the heart of, and captures, the innate moral dimension of all effective learning (Halliday, 1998; Hanson, 1998; Carr, 2005, 2006). Values education must therefore be at the centre of all pedagogy and, in turn, must employ the most updated pedagogies that, on the basis of research evidence, are most 
appropriate to the learning needs and capacities of students. It is here that the synergy between quality teaching and values education is one to be profitably considered, both in terms of the effectiveness of values education in whatever form it takes, and in terms of the further enrichment of quality teaching itself. To this end, this paper will explore the notion of quality teaching and its impact in recent literature and, having established a conceptual framework for it, will probe the implicit values dimension in quality teaching as well as identify the potential of quality teaching to transform the teaching of values. In making this case, data from the findings of the Australian Government’s values education initiative, the 'Values Education Good Practice Schools' project (VEGPS) will be drawn on for support. As well as referring to the Government report on Stage One of VEGPS (DEST, 2006), further reference will be made to the book that was sponsored by the Government in disseminating these findings in a more consumable form (Lovat \& Toomey, 2007). In this book, the synergy between values education and quality teaching is described as a 'double helix', taken from a genetics term that connotes a particularly interdependent relationship between two separate entities.

\section{The Power of Quality Teaching}

In the USA, it was the Carnegie Corporation's 1994 Task Force on Learning (Carnegie, 1996) that in many ways impelled the modern era of quality teaching. It represented a turning-point in the dominant conceptions placed on the role of the school and, in turn, on the power of teaching to effect change in student achievement. It also played a part in identifying the range of learning skills that should constitute student achievement. Beyond the more predictable aspects of intellectual development, the Task Force report introduced for the modern era notions of learning concerned with communication, empathy, reflection, self-management and the 
particularly intriguing notion of self-knowing. It was also explicit in making the point that, while heritage and upbringing could make a difference to the ease with which these forms of learning can be achieved, they were in no way certain predictors of success. Consistent with the era of quality teaching which the report in some ways ushered in, the final onus was placed on the school (especially the early years of school) and the teacher to make the difference.

Pointing to the inadequacy of surface learning, the Carnegie Report emphasized that effective learning unleashes within the learner the cognitive, affective and conative energies that engage, empower and effect learning of genuine depth. The nature of such a learning experience was elaborated by Newmann and Associates (1996; Newmann, Marks, \& Gamoran, 1996) whose work focussed on the pedagogical dynamics needed to involve students at sufficient 'intellectual depth' in order to motivate and empower their learning. This would mean restructuring the whole learning environment for the benefit of student achievement and would involve: pedagogical strategies and techniques used by teachers; catering for the diverse needs of students; organizing of schools for the express purpose of student achievement (school coherence); professional development of teachers; and the creation of a trustful, supportive ambience in the school, which Bryk and Schneider (1996; 2002) referred to as 'relational trust'. In the search for the successful restructuring of schools for the benefit of student achievement, Darling-Hammond (1996; 1998; 2000; Darling-Hammond \& Youngs, 2002), a member of the 1994 Carnegie Task Force, engaged in intensive work that underlined the crucial role of the teacher. Her work rendered evidence that student achievement is predicted less by student demographics, teacher salaries, levels of expenditure and class sizes than by a teacher's subject and pedagogical knowledge. High quality subject and pedagogical knowledge (or 'quality 
teaching') was proven to have the single greatest impact on student success, when measured against the wide array of other factors of influence. On the contrary, poor quality teaching was found to have a cumulative and enduring debilitative effect (cf. Fallon, 2003).

Extensive evidence-based research, literature searches and meta-analyses over the last decade have repeatedly demonstrated that the quality of the teaching and learning environment far outweighs disadvantages of gender, school principals, other school effects, family background, socio-economic status or disability (e.g. Alton-Lee, 2003; Avery, 1999; Hattie, 2004; King, Schroeder, \& Chawszczewski, 2001; Scheerens, Vermeulen, \& Pelgrum, 1989; Rowe, 2004). The power of the classroom effect has been variously rated at 16-60\% of total demonstrable effect (NZGME, 2005). In Canada, Willms' (2000) research in elementary schools shows that what happens in a classroom affects students' achievement in literacy and maths, but also their affective development in matters of self-esteem and sense of belonging, as well as in their general health and well-being. Hence, evidence is building that indicates that the potency of quality teaching is not restricted to pedagogical techniques solely concerned with subject content and academic processes, but that its efficacy also lies in attending to the affective dimension of teaching and learning.

\section{Stretching Conceptions of the Power of Teaching}

Quality teaching has been defined in various ways within different projects. Among the differences, however, there is a discernible pattern that has stretched the conception of 'teacher' beyond its former constraints. Beyond the expected criteria related to qualifications and updated skills, there are more subtle features that speak, for instance, of 'intellectual depth' (Carnegie, 1996; cf. Newmann \& Associates, 
1996). In Carnegie’s definition, this is a concept that identifies the need not only to drive students towards dealing with the full array of facts and details related to any topic (in other words to avoid surface factual learning), but to induct students into the skills of interpretation, communication, negotiation, and reflection. In a word, the teacher's job is well beyond preparing students for 'get the answer right' standardized testing, but to engage the students' more sophisticated skills levels around such features as 'communicative capacity' and 'self-reflection'. Communicative capacity takes in many of the dispositions necessary to a highly developed social conscience and self-reflection provides the essential basis for a truly integrated and owned personal morality. In other words, it is not just the surface factual learning so characteristic of education of old that is to be surpassed. It is surface learning in general that is to be traded-in in favour of a learning that engages the whole person in depth of cognition, social and emotional maturity, and self-knowledge.

Quality teaching research has illustrated the true and full power of the teacher to make a difference in student learning not only around the technical (or factual), but around the interpretive (or social) and reflective (or personal) as well (after Habermas, 1972; see also Lovat \& Smith, 2003). The essence of quality teaching lies in the synergy between intellectual depth, communicative competence, reflection, self-management, and self-knowing (Lovat, 2005). . In summary, quality teaching has alerted the educational community to the greater potential of teaching, including in such areas as personal and social values inculcation. As such, it has huge relevance for the world inhabited by a comprehensive and exhaustive values education (Clement, 2007). Moreover, the reverse case could be argued, namely, that when properly and comprehensively understood, values education has the potential to complement, 
complete and, at times, even to correct the goals implicit in quality teaching (Lovat, 2007).

\section{Quality Teaching and the Values Dimension}

If there is a criticism that might be levelled against quality teaching as it has been implemented systemically in places, it is that there is the potential over time for it to become a victim of instrumentalist thought and technicist practice in much the same way as many of the regimes it has superseded. Notions of intellectual depth, relevance and supportiveness have as much potential to be reduced to formulas, become fixed, politicized and supposedly easily measured and observed as were the notions of objectives, outcomes, competencies and indeed intellectual quotient (IQ) in earlier times. In this way, the formulas and the measurements of behaviour that sit behind these concepts become insular, uncritical and determined by the terms of their own making, in a sense in the way that is now generally said to have been true of IQ testing regimes of the past. If it is to endure, the challenge for regimes built around the notion of 'quality teaching' is to avoid, or at least temper, the inclination towards reductionism to those formulaic devices that appeal to systems in their desires and attempts to control and standardize the products of research. A focus on values and the complementarity of values education is one way in which this might be achieved, for this focus serves as a constant reminder that there is in fact no magic in a formula and that student achievement is a complex notion that defies ease of instrumentalist forms of measurement, being determined rather by a wide range of factors, some easily measured but some which could never be measured by even the cleverest of instruments. 
The values dimension therefore serves as a corrective to those technicist approaches to teaching that serve to reduce teaching performance to mechanistic and instrumentalist criteria, with the view that practice is values-free. This conception of teaching ignores the insights of people like Halliday (1998), Campbell, Kyriakides, Muijs, and Robinson (2004) and Carr (2005; 2006) who suggest the poverty and futility of a technicist-only frame of reference. Campbell et al. (2004) point out that most of the school effectiveness literature, although appearing to be values-free, is, in fact, based on the value of instrumental pragmatism. As a result, school effectiveness research has been insulated from the 'moral frame of education' and its reflection 'in more specific values underlying the teaching process’ (p. 456). In addition, Halliday (1998) maintains that teaching is a moral activity and that for teachers to maintain authenticity in their teaching they need to reflect constantly on the sort of people they are, the theories and beliefs that they hold and the constraints they are under.

Similarly, Carr $(2005,2006)$ points out that good teaching depends on the development of 'forms of insight, understanding, judgement, appreciation and sensibility' that are not able to be reduced to scientifically measurable technicalities (2006, p. 182). While not underestimating the necessity of technical competence for effective teaching, Carr argues that, beyond the essential competencies in pedagogical skills and classroom management techniques, there is an interpersonal dimension in teaching which is independent of technique. In fact, effective and competent teaching cannot occur without the acquisition of these appropriate qualities of character which require conscious and intentional self-development (cf. Hansen, 1998). Haberman (2002) emphasises that student success depends largely on the communicative ability of teachers to empathize and communicate intuitively with students in such a way as 
to bridge the cultural and social divides that would otherwise be barriers to student learning.

The significance of the communicative and affective aspects in the teaching-learning relationship cannot be underestimated. The inquiry into Boys’ Education by the House of Representatives Committee on Education by the Australian Government (2002) recognised that depth and quality of learning depended greatly on the creation and maintenance of mutual respect, care and trust in the student-teacher relationship. Comments of boys recorded in the Report clearly indicate that the establishment of an empathic relationship precedes the engagement of learning in depth. Successful operation of pedagogical skills and demonstration of subject knowledge, so vital to quality teaching, are highly dependent on a teacher's capacity to forge genuine caring relationships with the students. Scanlon's (2004) study of students' expectations of teachers not only shows that teachers need expert content and pedagogical knowledge, but it emphasizes the critical role in student success of the teacher's capacity to empathize with the needs of students and to communicate well with them.

In a related study, Louden et al. (2004) concluded that it was difficult to pick likely student effects from simple observation of teacher practice. In some extreme instances, the study seemed to find that superior student effect could actually emanate from situations where teacher practice was questionable in terms of the most updated content and pedagogy but, against this, where a positive relationship existed between teacher and student. One might caricature the findings of this study by suggesting that, lying behind the relationship between practitioner and student, was the far more powerful relationship between elder and younger person. 
This profound influence of the student-teacher relationship to affect student learning is observed by others. Hattie (2004) identified one of the five dimensions characteristic of expert teachers attending to the affective attributes of teaching as 'high respect for students'. In determining the features of positive learning, Brady (2005) elevates the importance of personal relationships, approachability, and the provision of a warm and empathic environment to at least the same level as the proficient implementation of pedagogical strategies. The quality of classroom relationships, according to Deakin-Crick and Wilson (2005), is critical in supporting the nurturing of those values, attitudes and dispositions needed to accept personal responsibility for life-long learning. This concurs with Wentzel’s (1997) findings that, when students feel valued and supported, they are likely to be more motivated to learn. Similarly, Khine and Fisher (2004) observed the powerfully determining effect of positive interaction on student learning. These studies reflect Noddings' (1997) observation that caring relationships usually precede students' engagement with experience and subject matter. This profound connection between values and a student's capacity and motivation to learn is articulated clearly by Cawsey (2002):

There is considerable anecdotal evidence .... that accomplished teachers recognise that the deepest levels of learning occur at the level of values, at the point where a student takes his or her learning and makes personal meaning from it. Without that connection at the values level, students can master the technical aspects of the curriculum but will be unlikely to value the learning experience or the school that provided it. (p. 82) 
These findings fit well with international literature concerned with effective organizational change and reform where, similarly, notions of trust and care have emerged as those that define much of the difference between organizations that function well and those that do not (Bryk \& Schneider, 1996, 2002). Bryk and Schneider (2002), for instance, note the following:

Trust relations culminate in important consequences at the organizational level, including more effective decision-making, enhanced social support for innovation, more efficient social control of adults' work and an expanded moral authority to 'go the extra mile' for the children. Relational trust ... is an organizational property ... its presence (or absence) has important consequences for the functioning of the school and its capacity to engage fundamental change. (p. 22)

Furthermore, Bryk and Schneider spell out the connotations of what they describe as 'relational trust' in the “... dynamic interplay among four considerations: respect, competence, personal regard for others, and integrity” (2002, p. 23). In turn, these considerations comprise the cornerstone of values education where it has been demonstrated to have had most impact on whole school cultures, such as in the work of Farrer and Hawkes at West Kidlington Public School in England (cf. Farrer, 2000; Hawkes, 2007).

\section{Quality Teaching and Explicit Values Education}

Recounting the practical experience of the impact of values education at West Kidlington Public School in Great Britain, under the educational leadership of Neil 
Hawkes, offers profound insight into the impact of values education on the quality of teaching and learning. In this instance, teacher attitudes and practices, curriculum both explicit and embedded, the school environment, and parental and community support were focussed on the betterment of student learning and achievement, understood in academic, affective, moral and spiritual terms. Fundamental to the approach at West Kidlington was respect for the child, with the forming of a relationship with each child being seen as essential to the fostering of each individual student's progress. Positive relationships between students, staff, parents and the wider community were a priority. Children were assumed to be reflective learners and emphasis was placed on creating the kind of environment wherein each child's capabilities could be supported, encouraged and engaged. Developing a stable emotional life so that children would be able to cope with the demands of secondary school without stress was regarded as being of primary importance and such attention was devoted to the emotional state of children because of its determining effect on their willingness to learn. The merit of the approach was seen in children who were emotionally stable, able to apply themselves to their learning and at ease in their relationships with adults. Furthermore, these positive effects flowed over to discipline and high academic performance (Farrer, 2000; Hawkes, 2007).

As the experience of West Kiddlington demonstrates, effective values education demands a web of relationships extending from the classroom to the whole school and to the parents and general community. The potent effects of positive and trusting interaction between school, family and wider community is observed in other studies (e.g. Leming 1993, 1994; Hunt, 2004), thus emphasising the need for congruence between the implicit values of the general curriculum, the structure of the learning 
environment and the wider school community, and the explicit teaching of values. Furthermore, the transformation that occurred at West Kiddlington suggests that the benefit of values education in impacting on the affective development of students has an inherent flow-on effect to student progress in academic learning as well. Reports of the EPPI-Centre of the University of London into the impact of citizenship education also suggests grounds for assuming a relationship between the provision of values education, delivered by means of high quality pedagogy, and student progress in both affective development and academic achievement (Deakin-Crick, Coates, Taylor, \& Ritchie, 2004; Deakin-Crick et al., 2005). Similarly, several studies in the USA focussed on character education and social and emotional learning present evidence of a link between the quality teaching of values and student wellbeing and academic attainment (Benninga, Berkowitz, Kuehn, \& Smith, 2003, 2006; Zins, Weissberg, Wang, \& Walberg, 2004).

The literature review provided has served to demonstrate that quality teaching and values education, conceived in terms of a 'double helix', have capacity to coalesce for effective leaning not only in the area of explicit values education but also to have potential to impact on students' affective and cognitive development more widely and even on their academic progress through school. In other words, the content and substance of values education has the potential to go to the very heart of the power of quality teaching by focussing teacher and system attention on those features of their professional practice that have most impact, namely the relationships of due care, mutual respect, fairness and positive modelling established with the student and, in turn, on the network of systemic 'relational trust' that results. 


\section{Effective Values Education and Best Practice Pedagogy}

One is reminded, many years on, of the caution against instrumentalist approaches to education that was provided by the eminent John Dewey in the early days of public education. He said that to depend overly on subject knowledge and methods was fatal to the best interests of education. He spoke, rather, of the need for a way of knowing that was about the cultivation of a mindset on the part of teachers that was, at one and the same time, self-reflective and directed towards instilling reflectivity, inquiry and a capacity for moral judiciousness on the part of students (cf. Dewey, 1964). Dewey would not be at all surprised with the findings of modern research noted above. He would also feel vindicated, in all likelihood, by the priority being given at present to values education in the broad and comprehensive way it is being conceived.

Another more recent but equally influential thinker worth mentioning in this context is Jurgen Habermas (1972; 1974; 1984; 1987; 1990). Habermas’s theory of knowing has been instrumental in much of the thought that educationists have seized on in attempting to deepen our understanding of learning and stretching conceptions of the role of the teacher (cf. Deakin-Crick \& Joldersma, 2007). Beyond the importance of empirical-analytic knowing (the knowing and understanding of facts and figures), Habermas spoke, when it was entirely unfashionable, of the more challenging and authentic learning of what he described as historical-hermeneutic or 'communicative knowledge' (the knowing and understanding that results from engagement and interrelationship with others) and of 'critical knowing' or 'self-reflectivity' (the knowing and understanding that comes from critique of all one’s sources of knowledge and ultimately from critique of one’s own self or, in Habermas’s terms, from knowing oneself, perhaps for the first time). For Habermas, this latter was the 
supreme knowledge that marked a point of one's having arrived as a human being. One might caricature him as saying 'There is no knowing without knowing the knower', and the knower is oneself. In a sense, the ultimate point of the learning game is to be found in knowing oneself, and the consequent change of belief and behaviour, that inevitably follows.

Communicative capacity is when the self-reflective knower comes to see his or her own life-world as just one that needs to function in a myriad of life-worlds, and so comes to possess communicative capacity. In a sense, this is a formula for the modern, globally competent, intercultural communicator. Beyond this, however, is the notion of communicative action. Here, the self-reflective knower takes a step beyond mere tolerance to take a stand both for justice and for oneself because one’s new found self, one's own integrity, is at stake. This is a concept about personal commitment, reliability and trustworthiness that spills over into practical action that makes a difference, or what Habermas describes as 'praxis'. It is the kind of action that can only come from the wellspring enshrined in the notion of self-reflectivity, from one who knows who they are, values the integrity of being authentic and commits oneself to establishing the kinds of caring and trusting relationships that bear the best fruits of human interactivity. This is the kind of transformation of thought and practice that quality teaching seems to be directed towards and that an effective values education program would appear to have capacity to enhance.

Habermas's thought provides a conceptual frame for the coalescing of quality teaching and values education. An implication of his thought is around the removal of any artificial division between knowing and values, since all knowing has an ethical 
component and is related in some way to human action, whether technical, communicative or reflective. This means that there is a values component in all learning, because knowing cannot be values-neutral, and, therefore, any learning entails an encounter with values related to a knowledge domain. The self-reflective element in knowing is the means by which implicit values of any knowledge domain become explicit to the knower and so are accepted or rejected as the basis for communicative action.

\section{Values Education and Good Practice Schools}

The Australian Government’s ‘Values Education Good Practice Schools’ project (VEGPS) emanated from a government commitment to Values Education, underpinned by a 2004 Federal Budget grant of A \$29.7 million and signalled in the development of a National Framework in Values Education (DEST, 2005). This framework served to set the scene for explicit engagement of the intersection between values education 'best practice pedagogy' and impelled a series of research and practice-based projects designed to test assumptions around this intersection. VEGPS was the largest of these projects, being aimed at the school sectors, public, private and religious, and consisting of 51 clusters of schools (316 schools) across the country and comprising two stages of development. It has offered to these schools and their university researcher advisors the opportunity to trial good practice pedagogy in relation to nominated values education projects. The VEGPS Stage 1 Final Report (DEST, 2006) illustrates that good values education cannot be taken for granted or left to chance but requires vision, leadership, intentionality, creativity, communication and cooperation. In fact, it requires the presence and active implementation of each of the qualities which combine to constitute the hallmarks of quality teaching: intellectual depth, communicative competence, reflection, self-management and self-knowing. 
The report makes it clear that good values education cannot be achieved in a purely didactic fashion but requires a web of interactions encompassing the whole school, parents and the wider community that supports the school. The executive summary of the Stage One report (DEST, 2006) refers to the evidence in the report that seems to point to the capacity for values education to have a profound effect on the total educational environment of a school, including teacher practice, classroom climate and ethos, student achievement, student attitudes and behaviour, student resilience and social skills, intellectual depth of teacher and student understanding, improved relationships of care and trust, and enhanced partnerships with parents and the community.

It is not surprising then, that of the six indicators of educational impacts of good practice values education listed in the VEGPS report, three directly refer to impacts on teachers regarding professional practice, communication and positive relations with students, involving an increase in teacher confidence and sense of fulfilment in teaching (DEST, 2006, pp. 1-2). The report indicates that values education is a function of the way that the school interacts as a community and that by approaching education mindfully, many aspects of the life of the school will be brought into alignment with the values being taught. It was the experience of several schools taking part in the study that values could not be taught effectively apart from examining the values which were implicit in the school culture and discipline. In MacMullin \& Scalfino (2007), for instance, the values of the school, its principal, teachers, students and parents, were taken as the starting-point for inculcating a values approach to schooling. These values were slowly drawn into a conversation with the 
wider values implicated in the National Framework's linking of values education and good practice pedagogy, so forcing on all stakeholders a deeper consideration of extant teaching policy and practice in the school, the relationships that endured between all stakeholders, especially between the principal and teachers with the students, and the school's stated and real priorities. The result was that policy, practice and the relationships between stakeholders were brought into greater alignment with those values that research was showing enhanced student effect most positively. Among other things, this case study showed that good practice values education requires: a whole-school approach; a positive, intentional and focussed school leadership; and patience, perseverance and consistency during implementation.

Similarly, Netherwood et al. (2007), in a very different approach to values education, shows the importance of beginning with the values that lie at the heart of the school community if one wishes ultimately to enhance the values approach to learning. This case study is sited in a remote part of Australia where the intersection between indigenous and non-indigenous values systems lies at the heart of the values education intention. Again, it took the extant values, including those pertaining to vast and ancient land and spirituality attachments, as the starting-point for constructing around the values implied in the National Framework a deepening of respect for diversity and an empowering of attachment to sacred places by all stakeholders. This case study illustrates particularly well that a central value of values education is that it cannot be imposed because morality implies ownership and autonomy.

It is clear that teachers cannot come to the task of values education without adequate preparation and the VEGPS report provides examples of the many ways that 
professional development and personal growth were intertwined in the experience of teachers as they planned and implemented values education. In Chapman, Cahill \& Holdsworth (2007), for instance, teachers reported on a newfound appreciation of consulting with students in order to achieve the best effects of pedagogy. In a service learning approach to values education, cast in the language of 'Student Action Teams', teachers reported the following:

As all members of the cluster became more comfortable in the Student Action Team framework, and handed over the responsibility of this project to the students, teachers realised that the way they had taught values was not necessarily meaningful to students. (In the words of one teacher): They have taught us what it is in their world, to hear, see and feel values. They have opened our eyes to how best to embed Values Education in their curriculum, their school culture and their community. More importantly, they changed the way all members of the cluster looked at classroom management and relationships. What we have ended up with is a framework for truly embedding Values Education for students, by students. (p. 37)

Indeed, professional development was the powerhouse for initiating and sustaining values education as it became an avenue for sharing of ideas amongst teachers and providing a means for the less enthusiastic to come on board (DEST, 2006: 59). There were reports of students and teachers becoming learners together and there were instances of student leadership of staff on the journey (DEST, 2006: 65). One cluster reported on the establishment of a 'community of inquiry' that engaged everyone 'in the circle of learning':

Everyone in the classroom exchange, teachers and students alike, became more conscious of trying to be respectful, trying to do their best, and trying to give others a fair go. We also found that by creating an environment where these values were constantly shaping classroom activity, student learning was improving, 
teachers and students were happier, and school was calmer. (DEST, 2006: 120)

Another cluster reports that members of staff were challenged to share the 'classroom journey with students' rather than 'controlling the classroom learning environment' (DEST, 2006: 151,, 154). The experience of still another cluster was that values education not only stimulated reflective thought on the part of the students, but just as profoundly on the part of the staff:

[The 'values journey' undergone] has provided many benefits to the students as far as a coordinated curriculum and learning experiences that have offered a sense of belonging, connectedness, resilience and a sense of self. However, there has been none more significant than the reflective change that has occurred in the participant teachers and schools. (DEST, 2006: 185)

Aspects of self-management and self-knowing are highlighted by the capacity of the quality teaching of values to bring about changes in student behaviour and its potential to transform the learning environment is evidenced by some schools reporting a calming effect on the learning environment. According to the report, changes in students' behaviour resulted from their reflection upon the meaning of values and on their own behaviour as evidenced by a reduction in the number of referrals for behaviour. One university associate reported of one school: 
Although their catchment area has not changed significantly in the past several years, the documented behaviour of students has improved significantly, evidenced in vastly reduced incidents and discipline reports and suspensions. The school is [quoting the principal] 'a much better place to be'. Children are 'well behaved', demonstrate improved self-control, relate better to each other and, most significantly, share with teachers a common language of expectations of values. Other evidence of this change in the social environment of the school is the significant rise in parental satisfaction - across all measures in the past two years. (p. 41)

Other schools indicated a 'ripple down effect' (p.178) where changes in teacher behaviour resulted in changes in student behaviour. Values education made a difference to the behavioural code of several schools where behaviour rules were stated positively rather than negatively, with the effect of transforming that school's ethos:

The way that most teachers model behaviour to the students has changed. The way many teachers speak to students has changed. It is now commonplace for teachers to speak to students in values terms, using the words from the National Values ... For example, if a child has hurt another child, we would bring to the child's attention the values of 'Respect', 'Care' and 'Compassion' as well as 'Responsibility' for our actions... As a staff we realise the 
importance of modelling good behaviour and the values are the basis for this. (p. 75)

Changes in student behaviour indicate changes in communicative capacity and selfmanagement on the part of students, but more significantly on the part of teachers as they modelled the values explicitly taught by creating a classroom climate conducive to quality teaching and learning. It is evident that values education has the capacity to extend the options of teachers in managing learning environments:

Significant changes in student behaviours can result from teachers having additional repertoires with which to manage learning environments. The professional development component of this project provided the skills and strategies that developed these repertoires of practice. (p. 179)

Associated with behavioural changes in students is the way that teachers communicate with and treat students:

Teachers report they are treating students with greater respect. (p. 139)

Values education can lead to changed professional practice in classrooms and, in particular, in the way teachers relate to and communicate with their students. (p. 35)

Hill and Vick (2007) report on the impact that an explicit values education approach to a peer support program, based on the values suggested by the National Framework 
led to professional development in terms of enhanced pedagogical awareness and a renewed focus on the relationships that obtain between the various school stakeholders.

Thus, the documented results of the VEGPS Project, Stage One,illustrate the dynamics of the reciprocal interaction of values education and quality teaching, with the effectiveness of values education being reflected in the quality of the teaching. It is evident that values education has the potential to bring transformational changes in the ethos of the school and the learning environment of the classroom, extending to student and teacher behaviour, beneficial effects on student motivation to learn and more than a hint of improved academic achievement. Engagement in the quality teaching of values begins with the adequate preparation of teachers, as the hallmarks of quality teaching must first take effect on their approach before it is available to their students.

\section{Conclusion}

This article has identified the implicit values dimension that appears to be evident in research findings around quality teaching. It has furthermore set out to demonstrate that maximizing the effects of quality teaching requires explicit attention to this values dimension and that this can be achieved through a well-crafted values education program. Some data have been brought forward from the Australian Government Values Education Good Practice Schools (VEGPS) program that appear to confirm the hypothesis that stands at the heart of the article. This hypothesis might be stated as follows: we live in a time where the findings from research around maximizing student effect suggest a central role for values education. No longer can values education be reserved for the periphery of pedagogical and curricular 
intentions, nor be exclusively held for those school systems that embrace moral formation as being at the heart of their purpose. The findings within demand that values education be at the heart of all pedagogical and curricular ventures and that any educational regime that sets out to exclude a values dimension in learning will be weakening its potential effects on all learning, including academic learning. In a word, the nature, shape and intent of values education has the potential to re-focus the attention of teachers and their systems on the fundamental item of all effective teaching, namely the teacher her or himself, including naturally the quality of the teacher's knowledge, content and pedagogy, but above and beyond all of these, on the teacher's capacity to form the kinds of relationships with students that convey their commitment and care and that become the basis of developing in them, as individuals, personal character and, together, tomorrow’s effective citizenry. Values education and quality teaching are cohering. Newfound evidence suggests they are properly referred to as co-existing in a ‘double helix’ relationship. 


\section{References}

Alton-Lee, A. (2003) Quality teaching for diverse students in schooling: Best evidence synthesis. Available online at: http://www.minedu.govt.nz/web/downloadable/dl8646_v1/quality-teachingfor-diverse-students-in-schoo.pdf (accessed 1 December, 2005).

Avery, P. G. (1999) Authentic assessment and instruction. Social Education, 63(6), pp. 368.

Benninga, J. S., Berkowitz, M. W., Kuehn, P., \& Smith, K. (2003). The relationship of character education implementation and academic achievement in elementary schools. Journal of Research in Character Education, 1(1), 19-31.

Benninga, J. S., Berkowitz, M. W., Kuehn, P., \& Smith, K. (2006). Character and Academics: What Good Schools Do. Phi Delta Kappan, 87, 448-452.

Brady, L. (2005) Dimensions of teaching. Curriculum and Teaching, 20(1), pp. 5-14.

Bryk, A. S., \& Schneider, B. (1996) Social trust: A moral resource for school improvement. (Chicago: Consortium on Chicago School Research. ERIC Document Service ED 412630).

Bryk, A. S., \& Schneider, B. (2002) Trust in schools: A core resource for improvement. (New York: Russell Sage Foundation).

Campbell, R. J., Kyriakides, L., Muijs, R. D., \& Robinson, W. (2004) Effective teaching and values: Some implications for research and teacher appraisal. Oxford Review of Education, 30(4), pp. 451-465.

Carnegie. (1996) Years of promise: A comprehensive learning strategy for America's children: Executive summary. Available online at: http://www.carnegie.org/sub/pubs/execsum.html (accessed 14 December, 2006). 
Carr, D. (2005) Personal and interpersonal relationships in education and teaching: A virtue ethical perspective. British Journal of Educational Studies, 53(3), pp. $255-271$.

Carr, D. (2006) Professional and personal values and virtues in teaching. Oxford Review of Education, 32(2), pp. 171-183.

Cawsey, C. (2002) Naming, measuring and modelling the values of public education, in S. Pascoe (Ed.), Values in education: College year book 2002, pp. 71-84 (Deakin West, A.C.T.: Australian College of Educators).

Central Advisory Council for Education, UK. (1967) Children and their Primary Schools ('The Plowden Report') (London: HMSO). Available online at: http://www.dg.dial.pipex.com/documents/plowden.shtml $\quad$ (accessed 21 December 2006).

Chapman, J., Cahill, S. \& Holdsworth, R. (2007). Student action teams, values education and quality teaching and learning. In T. Lovat \& R. Toomey (Eds.) Values education and quality teaching: The double helix effect. (pp. 28-48) Sydney: David Barlow Publishing.

Clement, N. (2007). Perspectives from research and practice in values education. In T. Lovat \& R. Toomey (Eds.) Values education and quality teaching: The double helix effect. (pp. 11-27) Sydney: David Barlow Publishing.

Coleman, J. S., Campbell, E., Hobson, E., McPartland, J., Mood, A., Weinfied, F., et al. (1966) Equality of educational opportunity. (Washington: U.S. Dept. of Health, Education, and Welfare, Office of Education). 
Cunningham, C. A. (2005). A certain reasoned art: The rise and fall of character education in America. In D. K. Lapsley \& F. C. Power (Eds.), Character psychology and character education (pp. 166-200). Notre Dame, IN: University of Notre Dame Press.

Darling-Hammond, L. (1996) What matters most: A competent teacher for every child. Phi Delta Kappan, 78(3), pp. 193-200.

Darling-Hammond, L. (1998) Teachers and teaching: Testing policy hypotheses from a National Commission report. Educational Researcher, 27(1), pp. 5-15.

Darling-Hammond, L. (2000) Teacher Quality and Student Achievement: A Review of State Policy Evidence. Education Policy Analysis Archives, 8(1). Available online at: Available online at: http://epaa.asu.edu/epaa/v8n1/ (accessed 6 February 2006).

Darling-Hammond, L., \& Youngs, P. (2002) Defining "Highly Qualified Teachers": What does "Scientifically-Based Research" actually tell us? Educational Researcher, 31(9), pp. 13-25.

Deakin Crick, R., Coates, M., Taylor, M. J., \& Ritchie, S. (2004). A systematic review of the impact of citizenship education on the provision of schooling. In Research Evidence on Education Library. London: EPPI-Centre, Social Science Research Unit, Institute of Education.

Deakin Crick, R., Taylor, M. J., Tew, M., Samuel, E., Durant, K., \& Richie, S. (2005). A systematic review of the impact of citizenship education on student learning and achievement. In Research Evidence in Education Library. London: EPPICentre, Social Science Research Unit, Institute of Education.

Deakin-Crick, R., \& Wilson, K. (2005) Being a learner: A virtue for the 21st century. British Journal of Educational Studies, 53(3), pp. 359-374. 
Deakin Crick, R., \& Joldersma, C. W. (2007). Habermas, lifelong learning and citizenship education. Studies in Philosophy and Education, 26(2), pp. 77-95.

DEST (2005). National framework for Values Education in Australian schools. Retrieved August 11, 2007, from http://www.valueseducation.edu.au/verve/_resources/

Framework_PDF_version_for_the_web_left_column_file_link.pdf

DEST. (2006) Implementing the National Framework for Values Education in Australian Schools: Report of the Values Education Good Practice Schools Project - Stage 1: Final Report September 2006 (Carlton South, Vic: Curriculum Corporation). Available online at: http://www.valueseducation.edu.au/values/default.asp?id=16381 (accessed 18 November 2006).

Fallon, D. (2003) Case study of a paradigm shift: The value of focusing on instruction. Available online at: http://www.ecs.org/clearinghouse/49/00/4900.htm (accessed 14 December, 2005).

Farrer, F. (2000) A quiet revolution: Encouraging positive values in our children. (London: Random House).

Haberman, M. (2002) Can teacher education close the achievement gap? Paper presented at the American Educational Research Association Symposium April 2, 2002, New Orleans, EducationNews.org. Available online at: http://www.nuatc.org/articles/articles_rec_by.html (accessed 8 March 2006).

Habermas, J. (1972) Knowledge and human interests (J. Shapiro, Trans.) (London: Heinemann).

Habermas, J. (1974) Theory and practice (J. Viertal, Trans.) (London: Heinmann). 
Habermas, J. (1984) The Theory of Communicative Action (T. McCarthy, Trans. Vol. One: Reason and the Rationalisation of Society) (Boston: Beacon Press).

Habermas, J. (1990) Moral consciousness and communicative action (C. Lenhardt \& S. W. Nicholsen, Trans.) (Cambridge, MA: Massachusetts Institute of Technology Press).

Habermas, J. (2001) The liberating power of symbols: Philosophical essays (P. Dews, Trans.) (Cambridge, UK: Polity Press).

Halliday, J. (1998) Technicism, reflective practice and authenticity in teacher education. Teaching and Teacher Education, 14(6), pp. 597-605.

Hansen, D. T. (1998) The moral is in the practice. Teaching and Teacher Education, 14(6), pp. 643-655.

Hattie, J. (2004) It's official: Teachers make a difference. Educare News, 144(February), pp. 24,26,28-31.

Hawkes, N. (2007). Values and quality teaching at West Kidlington Primary School.

In T. J. Lovat \& R. Toomey (Eds.), Values education and quality teaching:

The double helix effect (pp. 115-133). Sydney: David Barlow Publishing.

Hill, A. \& Vick, M. (2007). Moving values beyond the half hour: Peer leadership and school vision: Case study of Townsville cluster, Queensland. In T. Lovat \& R. Toomey (Eds.) Values education and quality teaching: The double helix effect. (pp. 69-90) Sydney: David Barlow Publishing.

House of Representatives Standing Committee on Education and Training. (2002) Boys: Getting it right: Report on the inquiry into the education of boys. Canberra, A.C.T.: The Parliament of the Commonwealth of Australia. Available online at: 
http://www.aph.gov.au/house/committee/edt/Eofb/index.htm (accessed December, 2005).

Hunt, A. (2004) Values: Taught or caught? Experiences of Year 3 students in a Uniting Church school. International Education Journal, 4(4), pp. 129-143.

Jencks, C., \& et al. (1972) Inequality: A reassessment of the effect of family and schooling in America. (New York: Basic Books).

Khine, M. S., \& Fisher, D. (2004) Teacher interaction in psychosocial learning environments: Cultural differences and their implications in science instruction. Research in Science and Technological Education, 22(1), pp. 99111.

King, M. B., Schroeder, J., \& Chawszczewski, D. (2001) Authentic assessment and student performance in Inclusive schools, Brief\#5: Research Institute on Secondary Education Reform (RISER) for Youth with Disabilities. Available online at: http://www.wcer.wisc.edu/riser/briefs.htm (accessed May 29. 2006).

Leming, J. S. (1993) In search of effective character education. Educational Leadership, 51(3), pp. 63-71.

Leming, J. S. (1994) Character Education and the Creation of Community [Electronic Version]. The Responsive Community, 4(4), 49-57. Available online at: http://www.gwu.edu/ ccps/rcq/issues/4-4.pdf (accessed 8 May 2006).

Lickona, T. (1993) The return of character education. Educational Leadership, 51(3), pp. 6-10.

Louden, W., Rohl, M., Barrat-Pugh, C., Brown, C., Cairney, T., Elderfield, J., et al. (2005) In teachers' hands: Effective literacy teaching practices in the early years of schooling (Australian Government Department of Education, Science 
and Training).

Available

online

at:

http://inteachershands.education.ecu.edu.au/ (accessed 27 November 2006).

Lovat, T. J. (2005) Values Education and Teachers' Work: A quality teaching $\begin{array}{lll}\text { perspective. } & \text { Available online at: }\end{array}$ http://www.valueseducation.edu.au/values/default.asp?id=8753 (accessed 28 November, 2006).

Lovat, T. J., \& Smith, D. (2003) Curriculum: Action on Reflection (Fourth ed.). (Sydney, Australia: Social Sciences Press).

Lovat, T. \& Toomey, R. (Eds.) (2007). Values education and quality teaching: The double helix effect. Sydney: David Barlow Publishing.

MacMullin, C. \& Scalfino, L. (2007). Placing values at the centre of school policy and classroom practice: Case study at Modbury School, South Australia. In T. Lovat \& R. Toomey (Eds.) Values education and quality teaching: The double helix effect. (pp. 49-68) Sydney: David Barlow Publishing.

Netherwood, K., Buchanan, J., Palmer, D., Stocker, L. \& Down, B. (2007). Valuing diversity in children's voice: Case study of the Western Australian cluster. In T. Lovat \& R. Toomey (Eds.) Values education and quality teaching: The double helix effect. (pp. 91-114) Sydney: David Barlow Publishing.

Newmann, F. M., \& Associates. (1996) Authentic achievement: Restructuring schools for intellectual quality (1st ed.). (San Francisco: Jossey-Bass Publishers).

Newmann, F. M., Marks, H. M., \& Gamoran, A. (1996) Authentic pedagogy and student performance. American Journal of Education, 104280-312. 
Noddings, N. (1997) Character education and community, in A. Molnar (Ed.), The construction of children's character, pp. 1-16 (Chicago \&Great Britain: NSSE).

NZGME. (2005, 13 April) Impact of teaching and schools on variance in outcomes, New Zealand Government Ministry of Education. Available online at: http://www.minedu.govt.nz/index.cfm?layout=document\&documentid=8679\& data=l (accessed 10 February, 2006).

Reynolds, D., Hargreaves, A., \& Blackstone, T. (1980) Review Symposium of Rutter et al. Fifteen thousand hours, British Journal of Sociology of Education, 1(2), pp. 207-219.

Rowe, K. J. (2004) In good hands? The importance of teacher quality. Educare News, 1494-14.

Scanlon, L. (2004) 'She just blends and just comes down to our level and communicates with us like we're people': Students' perceptions of quality teaching and teaching standards. Change: Transformations in Education, 7(1), pp. 93-108.

Scheerens, J., Vermeulen, C. J. A. J., \& Pelgrum, W. J. (1989) Generalizability of instructional and school effectiveness indicators across nations. International Journal of Educational Research, 13(7), pp. 789-799.

Wentzel, K. R. (1997) Student motivation in middle school: The role of perceived pedagogical caring. Journal of Educational Psychology, 89(3), pp. 411-419.

Willms, J. D. (2000) Monitoring school performance for standards-based reform. Evaluation and Research in Education, 14(3\&4), pp. 237-253. 
Zins, J. E., Weissberg, R. P., Wang, M., \& Walberg, H. J. (Eds.). (2004). Building academic success on social and emotional learning: What does the research say? New York; London: Teachers College Press.

Professor Terence Lovat is Professor of Education and Pro Vice-Chancellor at The University of Newcastle, Australia. He is the chief investigator on the Australian Council of Deans of Education Values Education Project and the national coordinator of the University Associates Network attached to the Values Education Good Practice Schools Project. Both projects emanate from the Australian Government's Values Education Program and are managed by Curriculum Corporation, Australia.

Dr Neville Clement is a research associate at The University of Newcastle, Australia. His main work is associated with research support for the various projects of the Australian Government's Values Education Program for which the University of Newcastle is responsible 